Vol 2. No 2. Agustus 2018

ISSN 2580-5029

\title{
Potency of Curculigo capitulata and Curculigo latifolia Fruit Based on Nutrient Content (a Case for Preservation Need in Kebonharjo)
}

\author{
Marbelisa Briliani ${ }^{*}$, Mayang Christy Perdana ${ }^{1}$, Imerda Yuan Perwirasari ${ }^{1}$, Ika Feni \\ Setiyaningrum¹, Sri Rum Giyarsih ${ }^{2}$, Eko Haryono²
}

1Environmental Science Program, Graduate School of Universitas Gadjah Mada, Yogyakarta, Indonesia

${ }^{2}$ Faculty of Geography, Universitas Gadjah Mada, Yogyakarta, Indonesia

*Email: mayyoung780@gmail.com

\begin{abstract}
C. capitulata and C. latofilia are recognized as a medical plants in Asia, especially for ancient India and China. In Indonesia, i.e Kebonharjo (a village in Samigaluh District, Kulon Progo, Yogyakarta), people use it as a sweetener replacing sugar. Phenol, neonorlignan, and protein inside these plants had been examined by some researchers. However, the nutrient content inside the fruit are rare or slight recorded. This study aims to reveal the composition of minerals ( $\mathrm{Ca}, \mathrm{Fe}, \mathrm{Mg}, \mathrm{K}$ ), carbohydrate compound (glucose, fructose, sucrose) and Vitamin $C$ in their fruit, therefore, the development to preserve these species can be concerned due to the plan of "Bedah Menoreh" program, a program of road construction connecting between New Yogyakarta International Airport (NYIA) and Borobudur Temple. The method for finding out the nutrient content is by laboratorium analysis. Result showed that both fruit contained potentially high of mineral, especially Ca (calcium), but C.capitulata and C.latifolia contained no sucrose and glucose respectively.
\end{abstract}

Keywords: C.capitulata, C.latifolia, nutrients, preservation

\begin{abstract}
ABSTRAK
C. capitulata dan C. latofilia diakui sebagai tanaman medis di Asia, terutama pada masa India dan Cina kuno. Di Indonesia, khususnya Kebonharjo (sebuah desa di Kecamatan Samigaluh, Kulon Progo, Yogyakarta), beberapa warga menggunakannya sebagai pemanis sebagai pengganti gula. Adanya kandungan fenol, neonorlignan, dan protein di dalam tanaman ini telah dieksplorasi oleh beberapa peneliti. Namun, tidak banyak sumber informasi yang ditemukan mengenai kandungan nutrisi di dalam organ buah. Penelitian ini bertujuan untuk mengungkap komposisi mineral (Ca, $\mathrm{Fe}, \mathrm{Mg}, \mathrm{K}$ ), senyawa karbohidrat (glukosa, fruktosa, sukrosa) dan Vitamin $\mathrm{C}$ pada organ buah $\mathrm{C}$. capitulata dan C. latifolia. Dengan demikian, pengembangan untuk melestarikan spesies ini dapat menjadi perhatian terkait adanya rencana pembangunan "Bedah Menoreh", yakni sebuah program pembangunan infrastruktur jalan raya yang menghubungkan antara New Yogyakarta International Airport (NYIA) dan Candi Borobudur. Metode yang digunakan untuk mengetahui kandungan nutrisi dalam buah kedua spesies ini adalah melalui analisis laboratorium. Hasil penelitian menunjukkan bahwa kedua buah mengandung mineral yang tinggi, terutama Ca (kalsium), tetapi C. capitulata dan C. latifolia tidak mengandung sukrosa dan glukosa.
\end{abstract}

Kata Kunci: C. capitulata, C. latifolia, nutrien, kelestarian 


\section{INTRODUCTION}

The threat of loss of biological resources potency may occur. Indonesia's biodiversity has been partially exploited, some newly known to its potential, and some unknown. Basically, biodiversity can recover, but this ability is limited. The potential of biological resources as development capital gives an assumption that the existence of biodiversity is very dependent on human treatment (Astirin, 2000).

Lane development plan of "Bedah Menoreh" is one of Kulon Progo Regency's programs as a response of the "New Yogyakarta International Airport (NYIA)" construction. This lane will directly road-connected between NYIA and Borobudur Temple. Government hopes that it'll be an opportunity in raising community's prosperity, especially for those who will be passed through its lane due to the rise of tourists.

Regarding to its plan, the hidden potency of biodiversity which has been unknown yet by the community must be explored. This is such an important since the worry of biodiversity loss. On the other hand, the potential of biological resources can support development, especially in the economic field. With the enactment of Law no. 22 of 1999 on Regional Government and Law no. Law
No. 25/1999 on Central and Regional Financial Balance, regional readiness for broad autonomy is required, including a review of the potential resources of development and sustainable management of these resources. Various efforts must be geared to explore the potential of natural resources of a region (province or distric/city) for the increase of local revenues as a source of regional development (Sugandhy, 2001).

\section{Curculigo capitulata (palm grass)}

and Curculigo latifolia (lemba) are uniquely called "Nyangkuh" and "Klembek" by villagers of Kebonharjo, Kulon Progo, Yogyakarta. Both can be found along the wild yard in this area. So far, this plant is still unutilized by the villagers, since many villagers haven't known their usabilities. Both plants have already existed for many years in Kebonharjo. However, today, they begin difficult to find. Some knows that their fruit have sweet taste and can be used as replacement of sugar for drinks. Brink (2003) recorded that they produce a very sweet aftertaste when a drink is taken after eating the fruit. It is also used to sweeten the sour food. Curculigo spp. are shade-loving plants. It needs water in large amount. It also prefers growing in rich organic matter. In Java, C. capitulata 
occurs in primary and secondary forest up to $2000 \mathrm{~m}$ altitude and C. latifolia in rain forest up to $1100 \mathrm{~m}$ altitude. However, lack of information provides the nutrients composition contained in $C$. capitulata and C. latifolia, so this study aims to reveal the composition minerals ( $\mathrm{Ca}, \mathrm{Fe}, \mathrm{Mg}, \mathrm{K}$ ), sugar compound (glucose, fructose, sucrose) and Vitamin $C$ in their fruit, therefore, the development to preserve these species in Kebonharjo can be taken as a concern.

Based on that matters, it is necessary to study the hidden potency of C. capitulata and C. latifolia in case of nutrient content which has not been widely known by the community. By knowing this, prevention of its loss can be minimized, and increase of the community's economy regional income based on its preservation can be done.

\section{Curculigo capitulata}

C. capitulata is useful to be used as a traditional medicine since ancient India and China as a treatment for hemorrhoids, asthma, jaundice, diarrhea, colic and gonorrhea. The rhizome is used for treating a bronchitis in Sichuan province (Nie et al., 2013). Choudhury and Shil (2005) reported that Curculigo capitulata contains antibacterial against Streptococcus sp. C. capitulata reaches from South Asia (India, Sri Lanka,
Bangladesh, Nepal) through South-East Asia to Taiwan, Australia and the Pacific Islands (Solomon Islands, Hawaii). It is hairy herb, up to $1.5 \mathrm{~m}$ tall. Fruit (Figure 1) globose to ovoid, $10-15 \mathrm{~mm}$ long, not beaked, whitish to green, pulp white, and not very sweet (Brink, 2003). Although it's not as sweet as Curculigo latifolia, but the sweetness is left in throat after tasting.

\section{Curculigo latofolia}

Curculigo consists of about 20 species spread over the tropics, but most species are also cultivated throughout the world as ornamental plants. In Malaysia, 5 species are indigenous. Curculigo latifolia are commonly found in South Asia (India, Sri Lanka, Bangladesh, Nepal) through Southeast Asia to Taiwan, Australia and the Pacific Islands (Solomon Islands, Hawaii), Malaysia: Malaysia Peninsula, Singapore, Indonesia (Sumatra, Java, Sulawesi, Maluku), Philippines (Luzon, Negros, Biliran, Mindanao), New Guinea and Manus Island (Brink, 2003).

Many natural compounds had been investigated in both C. capitulata and $C$. latifolia, as if Chang and Lee (1998) found neonorlignan and phenols isolated from C. capitulata and even Shirasuka et al. (2004) discovered neoculin as a tastemodifying protein besides curculin. 
Ranjbarfard et al. (2014) stated that $C$. latifolia has a great potency to be developed in pharmaceutical industry, since all parts of its plant raise medical benefit.

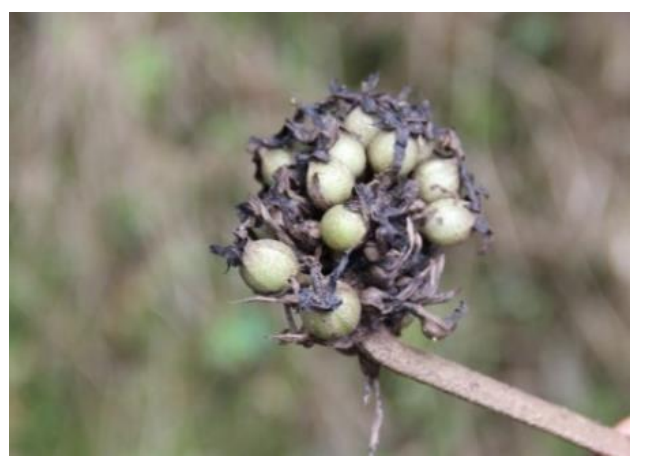

Figure 1. C. capitulata Fruit (Source: Personal Documentation, 2018)

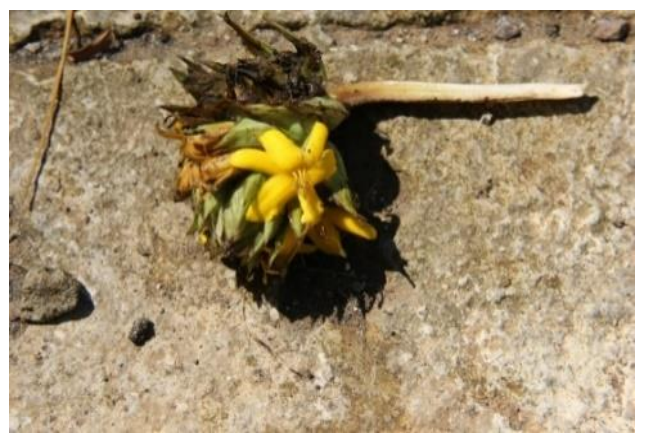

Figure 2. C. latifolia Fruit (Source: Personal Documentation, 2018)

\section{RESEARCH METHOD}

\section{Source of Sample}

Sample of $C$. capitalata and $C$. latifolia were collected in wild yard of Kebonharjo, Samigaluh District, Kulon Progo, Yogyakarta.

\section{Laboratorium Analysis}

The sample pervaded ripe fruit of C.capitulata and C.latifolia. Mineral test namely $\mathrm{Ca}, \mathrm{Fe}, \mathrm{Mg}$, and $\mathrm{K}$ was conducted in BBTKLPP (Balai Besar Teknik Kesehatan Lingkungan dan Pengendalian Pencemaran) Yogyakarta, while Glucose, Fructose, Sucrose, and Vitamin C were conducted in Yogyakarta Health Laboratory Service (Balai Laboratrium Kesehatan Yogyakarta). Ca and Mg test method used "USEPA 3051, APHA, 2012, Section 3120 B", Fe used "USEPA 3051, SW 846-7000 B.2007", K used SNI 134719-1998". Glucose, Fructose, Sucrose, and Vitamin $\mathrm{C}$ test method used titrimetric.

\section{RESULT AND DISCUSSION}

From the result which is shown by Table 1 (both $C$. capitulata and $C$. latifolia), tends to contain more minerals than other nutrients in this study. The highest value among eight nutrients tested presents by Ca namely 3,101.57 mg/100gr for C. capitulata and 3,452.01 $\mathrm{mg} / 100 \mathrm{gr}$ for C. latifolia. C. latifolia occupies higher value in almost all minerals content, except Mg.

From the Table 1 can be also concluded that in term of sugar, $C$. capitulata (Nyangkuh) doesn't contain any sucrose, while C. latifolia (Klembek) doesn't contain any glucose. This result reveals that the sweet taste of both fruit is not caused by carbohydrate. 
Table 1. Fruit Nutrients Content in C.capitulata and C.latifolia (mg/100gr)

\begin{tabular}{ccc}
\hline Nutrients & $\begin{array}{c}\boldsymbol{C} . \\
\text { Capitulata }\end{array}$ & $\begin{array}{c}\boldsymbol{C} \text {. } \\
\text { latifolia }\end{array}$ \\
\hline Glucose & 1.94 & 0 \\
Fructose & 1.96 & 1.08 \\
Sucrose & 0 & 1.08 \\
Vit.C & 18.06 & 5.61 \\
$\mathrm{Ca}$ & $3,101.57$ & $3,452.01$ \\
$\mathrm{Fe}$ & 36.356 & 872.93 \\
$\mathrm{Mg}$ & 311.584 & 117.6 \\
$\mathrm{~K}$ & 0.222 & 0.41 \\
\hline
\end{tabular}

Source : Result from BBTKLPP, 2018

Being compared with other fruit, $C$. capitulata doesn't have much Vit. C as either white guava (116 mg/100gr) or papaya (85.3 mg/100gr). However, it has a lot more Ca $(3,101.57 \mathrm{mg} / 100 \mathrm{gr})$ and Fe (36.356mg/100/gr) than white guava which only contains $31 \mathrm{mg} / 100 \mathrm{gr} \mathrm{Ca}$ and $0.2 \mathrm{mg} / 100 \mathrm{gr}$ Fe (Indonesia Nutrient Composition List, 1995). Curculigo latifolia ("klembek") has various mineral content such as shown by Table 1 . Consumption of this fruit can be a supply of minerals for one's nutritional needs. Furthermore, the absence of glucose content makes $C$. latifolia safe for consumption for diabetics.

According to the data of nutrition sufficiency (AKG) issued by the Ministry of Health RI based on PermenKes RI no. 75 Year 2013, for calcium mineral adequacy rates ranging from 200-1300 mg / day for the age of infants to pregnant women and lactating mothers.
By consuming 50 grams of both fruits is able to meet the needs of calcium (Ca) for pregnant women, and less than 50 grams for the baby's age. As for the mineral adequacy ( $\mathrm{Fe}$ ), based on the AKG from the Ministry of Health RI is about 7-39 $\mathrm{mg} /$ day.

In term of $\mathrm{Fe}$ (iron) content, $C$. latifolia is greater than C. capitulata.To meet the needs of iron, can be consumed as much as 1-5 grams C.latifolia per day. In the other hand, C.capitulata is rich of Mg than C.latifolia. Consuming 100 grams to $1 \mathrm{~kg}$ of $\mathrm{C}$. latifolia is able to meet the needs of potassium content for the people of Indonesia.

The content of vitamin $C$ from fruit is $5.61 \mathrm{mg} / \mathrm{g}$. To meet the nutritional adequacy rate of Indonesians, ranging from infant age, adult, to pregnant and lactating mothers with a vitamin $C$ value of 40-115 mg / day, it takes about 8-22 grams / day. The level of glucose and fructose from this piece of fruit each of them is $1.08 \%$, while sucrose is $0.00 \%$.

\section{CONCLUSION}

C.latifolia and C.capitulata are potentially preserved in Kebonharjo based on their nutrient content. Mineral such as calcium is the highest content compared to one of mostly known fruit i.e guava. Both of them are safe to be 
consumed by diabetics since contain low even absence of sugar (glucose of C.latifolia, sucrose for C.capitulata). Regarding to this, preservation of these species are important to avoid its loss related to "Bedah Menoreh Program".

\section{REFERENCES}

Astirin, Okid Parama, 2000.Permasalahan Pengelolaan Keanekaragaman Hayati di Indonesia. Biodiversitas. 1(1) : 1-5.

Brink, M., 2003. Curculigo Gaertn. In: Brink, $\mathrm{M}$ and Escobin, R.P. (Editors). Plant Resources of South-East Asia No. 17: Fibre plants, Backhuys Publisher, Leiden, The Netherlands

Chang, Wen-Liang. and Lee, Shoei-Seng. 1998. Norneolignan and phenols from Curculigo capitulate. Phytochemistry 49(7):2133-2136.

Choudhury, M.D. and Shil, S., 2005. Antibacterial activity of some ethnomedicinal plants, Annals of Biology. 21: 187-192.

Kemenkes RI. 2013. Permenkes RI No. 75 Taun 2013 : Angka Kecukupan Gizi yang Dianjurkan bagi Bangsa Indonesia. Kemenkes RI.

Shirasuka Y, Nakajima K, Asakura T, Yamashita H, Yamamoto A, Hata S, Nagata S, Abo M, Sorimachi H, Abe K. 2004. Neoculin as a new tastemodifying protein occurring in the fruit of Curculigo latifolia. Biosci Biotech Bioch. 68(6): 1403-1407.

Sugandhy, Aca, 2001. Potensi Sumber Daya Hayati sebagai Penunjang Pembangunan Daerah yang
Berkelanjutan. Edisi Khusus Masalah Cendana NTT Berita Biologi, 5 :1-7.

Nie, Yan., Dong, Xin Yongjing He, TingtingYuan, Ting Han, Khalid Rahman, Luping Qin, Qiaoyan Zhang. 2013. Medicinal plants of genus Curculigo: Traditional uses and a phytochemical and ethnopharmacological review. Journal of Ethnopharmacology 147: 547-563. 